\title{
Editorial
}

\section{Climate strikes to Extinction Rebellion: environmental activism shaping our future}

\section{THE RISE OF ENVIRONMENTAL ACTIVISM}

Covid-19 has dominated global news in 2020, but even the pandemic has not stymied a new generation of activists mobilizing for action on interconnected grievances of climate breakdown, economic inequality and social injustice.

Numerous countries have experienced the mass mobilizations of Extinction Rebellion (XR), the youth-led climate strikes associated with Greta Thunberg and the Black Lives Matter (BLM) rallies, as well as localized protests such as Indigenous First Nations blockading oil pipelines and railways on their traditional territories. With electoral politics struggling to generate the ambitious laws urgently needed to avert irreparable environmental breakdown, many have turned to protest. Protest mobilizations embrace diverse grievances, goals and strategies, and indeed some may seem to be highly reactionary, such as France's Yellow Vests movement (Mouvement des gilets jaunes) sparked by higher fuel taxes to combat carbon emissions. The contemporary protests however share some intersecting points of interest for scholars researching the influence of civil disobedience, the roles of grassroots activists challenging state or corporate elites, the policing of protesters' space and voice, the breakdown in the legitimacy of the nation-state and the increasing invocation of emergency powers in unsettled times.

Environment-related protest of course is not new, and draws sustenance from a long tradition of grassroots activism including the Occupy movement, the anti-globalization and anti-nuclear movements, and earlier civil disobedience campaigns associated with black civil rights and the Suffragettes. ${ }^{1}$ The recent social upheavals - the subject of this special issue of the Journal of Human Rights and the Environment - involve some shifts away from these precedents, shifts including the rise of a rhetoric of a climate or planetary 'emergency'; the emergence of new political actors, notably children; and the deployment of distinctive tactics such as the hyper-aesthetic character of some protests, as is evident in XR's street performances and paraphernalia. Concurrently, some governments have recently introduced unprecedented measures to thwart environmental activism, including anti-protest laws that criminalize some forms of activism.

The modern era of environmental law, dating from about the 1960s, has brought many benefits, such as cleaner air and water, greater due diligence on proposed developments, and larger protected areas networks. Many of these laws have also enhanced opportunities for public participation in decision making and access to justice, thereby

1. L Perry, Civil Disobedience: An American Tradition (Yale University Press, New Haven 2013); M Giugni, Social Protest and Policy Change: Ecology, Antinuclear, and Peace Movements in Comparative Perspective (Rowman and Littlefield, Lanham 2004). 
channelling protesters off the streets into administrative and judicial forums where elites hoped to appease or defuse environmental grievances. ${ }^{2}$ Legislation such as the United States' National Environmental Policy Act 1969, and in the Australian state of New South Wales, the Environmental Planning and Assessment Act 1979 and Land and Environment Court Act 1979, gave broad rights for public participation in decision making, including the rights to be consulted, to be informed in environmental impact assessments, and of access to the courts. However, the failure of these laws to cope with a new generation of larger environmental upheavals, from climate change to marine plastic pollution, has become apparent with the unleashing of a wave of dissent and activism. Global carbon emissions have continued to grow in recent decades despite international agreements and national legislation ostensibly aimed at mitigating climate change, and a heightened sense of urgency that time is running out for bold enough action has emerged. ${ }^{3}$

This impasse has stirred a new impetus to environmental activism, with some abandoning the 'reformist' pathway associated with the polyarchal institutions of liberal-democratic systems in favour of mass mobilization and civil disobedience. This shift is epitomized strongly in the XR movement, whose members block traffic in city centres, stage mass 'die-ins' and disrupt public transport in the hope of overwhelming law-and-order authorities and forcing governments to act. Mass rallies, notably the climate strikes in September 2019 that swept many cities worldwide, represent another prong of the new activism, involving tens of thousands of participants, especially children and youth. Whilst such huge rallies have been generally lawful assemblies, they have also sought to harness the mass media to convey the unprecedented scale of public anxiety about looming climate breakdown, with the hope of catalysing action, from fossil fuels divestment to official declarations of a climate emergency. ${ }^{4}$

\section{ANTI-PROTEST LAWS AND EMERGENCIES}

The foregoing momentum has in some jurisdictions been challenged by hostile governments with anti-protest legislation, and the Covid-19 pandemic has given governments an additional tool, under the guise of public health regulations, to restrict public gatherings or 'non-essential' movement. Australia demonstrates both tendencies. State governments, specifically in New South Wales and Tasmania, have introduced anti-protest laws with broad police powers, vague offences and severe penalties that signal the prioritization of business operations over the rights of individuals to peacefully protest. ${ }^{5}$ Specifically targeting XR activists, the Queensland government in late 2019 banned lock-on devices, which have been used in some blockades whereby protesters chain themselves to gates or fences, with violations incurring penalties of up to two years' imprisonment or fines. ${ }^{6}$ The Covid-19 lockdowns have also been used to

2. For a useful historical overview in regard to United States environmental law, see R Lazarus, The Making of Environmental Law (University of Chicago Press, Chicago 2007).

3. World Meteorological Organization (WMO), WMO Statement on the State of the Global Climate in 2019 (WMO, Geneva 2020).

4. BJ Richardson, 'Divesting from Climate Change: The Road to Influence' (2017) 39(4) Law and Policy 325.

5. Eg, Workplaces (Protection from Protesters) Amendment Bill 2019 (Tas); Right to Farm Act 2019 (NSW).

6. Summary Offences and Other Legislation Amendment Act 2019 (Qld). 
restrict environmental activists, as recently occurred in Tasmania when anti-logging protesters were charged for violating non-essential travel restrictions. ${ }^{7}$ Also during the current pandemic, in the United States the governors of Kentucky, South Dakota and West Virginia have approved laws designating gas and oil infrastructure (eg pipelines) as 'critical infrastructure' to be protected from any interference, with offenders facing draconian criminal penalties. ${ }^{8}$ Such reactions exemplify a phenomenon that Naomi Klein dubs 'the shock doctrine': the practice whereby business and political elites collude to introduce controversial changes to the law under the pretext of a national emergency. ${ }^{9}$

Yet, environmentalists have also invoked the language of emergency - the climate emergency - to justify their stance, and indeed some activists are taking this defence into the courtroom. The first case to affirm the climate emergency as a necessity defence to criminal conduct was in 2008 in England. Six Greenpeace activists were charged with $£ 30000$ of criminal damage to a coal-fired power station, which they had sought to disrupt by scaling its chimney to place graffiti shaming the then UK Prime Minister Gordon Brown. The jury absolved them following evidence from climate scientist Jim Hansen that the 20000 tonnes of carbon dioxide spewing from this facility each day - equivalent to all of the world's 30 least polluting countries - would contribute to the extinction of up to 400 species and to sea level rises predicted to inundate English coastlines. ${ }^{10}$

The climate emergency defence was invoked with mixed success in 2019 and 2020 by XR protesters in Australia and the United Kingdom. Courts upheld the defence in two English cases but rejected it in two trials in Queensland. One success was when a London jury found XR activists Roger Hallam and David Durant innocent of charges arising from their spray chalking a university building with anti-fossil-fuel messages. ${ }^{11}$ The jury ignored instructions from the judge that the defendants' fear of climate change was irrelevant to the legality of their actions. Conversely, the climate emergency defence was rejected in June 2020 by a Queensland magistrate, sitting without a jury, who convicted and fined three XR activists for obstructing city traffic. ${ }^{12}$ Interestingly, the magistrate acknowledged evidence tendered of a climate emergency, and that the defendants reasonably believed they had to protest about it, but he found no evidence that it was 'necessary' for the trio to behave in the specific manner they chose, blocking city traffic. ${ }^{13}$ However, in a more recent ruling in August 2020

7. 'Logging Protesters Charged', Tasmania Talks, 22 May 2020, <http://www.tasmaniatalks. com.au/newsroom/tasmanian-news/49879-logging-protesters-charged>.

8. A Kaufman, 'States Quietly Pass Laws Criminalizing Fossil Fuel Protests Amid Coronavirus Chaos', Huffington Post, 28 March 2020, <http://www.huffingtonpost.com.au/entry/pipelineprotest-laws-coronavirus_n_5e7e7570c5b6256a7a2aab41?ri18n=true $>$.

9. $\quad \mathrm{N}$ Klein, The Shock Doctrine: The Rise of Disaster Capitalism (Knopf Canada, Toronto 2009).

10. J Vidal, 'Not Guilty: Greenpeace Activists Who Used Climate Change as a Legal Defence', Guardian, 11 September 2008 <http://www.theguardian.com/environment/2008/ sep/11/activists.kingsnorthclimatecamp>.

11. I Kaminski, 'Climate Activists Win Necessity Defense Case in London', Climate Liability News, 10 May 2019 <http://www.climateliabilitynews.org/2019/05/10/necessity-defense-climatechange-activists>.

12. 'Extinction Rebellion Fined as Court Rejects Climate Defence', Queensland Times, 26 June $2020<$ https://www.qt.com.au/>.

13. Comments from defendants' solicitor conveyed in correspondence from Nicole Rogers, Southern Cross University School of Law and Justice. 
on an appeal by two young climate protesters, the Queensland District Court overturned their criminal convictions and gaol sentences in connection with their using lock-on devices when blocking a railway line servicing a coal mine. The Court accepted that the political motivation of the two protesters - to advocate for better climate policy in response to the devastating Australian bushfires of 2019-2020 'lessen[ed] their moral culpability', and accordingly reduced their sentences to a $\$ 1000$ fine with no conviction recorded. ${ }^{14}$ The Court also rejected the original magistrate's view that the protesters' actions had exposed people to risk of injury or damage to property - a stance at odds with the rationale of the government's punitive criminalization of the use of lock-on devices in protests.

With some national and local governments increasingly acknowledging a climate emergency, one might hope that courts should soon become more receptive to excusing the ostensible criminality of some civil disobedience. Yet, climate breakdown is not commonly perceived as an emergency in the conventional understanding: a feeling of impending danger such as a house on fire. Instead, the threat of climate breakdown enters our lives vicariously via documentary films and news of scientific studies, some of which can indirectly touch our emotions with images of starving polar bears, melting glaciers or raging forest fires, albeit usually remote from one's daily life. Much of the upheaval of climate change involves slow, accretive violence, over many decades, such as rising seas or ocean acidification. The sensory deficits and temporal displacements of a changing climate and its impacts thus deprive global warming of the visceral power to terrify us. ${ }^{15}$

Our sensory deficits of the horrors of climate change create a broader challenge for environmental activists in winning the hearts and minds of the general public. Mass dissemination of climate science though data, charts and graphs has so far been insufficient to generate the critical tipping points of support sought by groups such as XR as well by green parties in electoral politics. On the other hand, a 17-year-old autistic teenager without any scientific qualifications, Greta Thunberg, has been extraordinarily effective in rallying support for her crusade for urgent climate action. ${ }^{16} \mathrm{Her}$ meteoritic rise to global stardom offers lessons for the wider climate activism movement about its choice of messengers and messages. These developments also raise fascinating enquiries for scholars interested in the future of environmental law in times of increasing social unrest and protest.

\section{PROTEST MOVEMENTS, ACTORS AND THE PUBLIC SPHERE}

The seven articles comprising this special issue of the Journal of Human Rights and the Environment, recruited via an open, international call, reflect a wide variety of perspectives about environmental activism and protest. Some authors explore the subject matter through broad, multi-jurisdictional themes, while others focus on specific jurisdictions

14. EH v QPS; GS v QPS [2020] QDC 205, at para 77.

15. See further BJ Richardson, The Art of Environmental Law: Governing with Aesthetics (Hart Publishing, Oxford 2019); BJ Richardson, Time and Environmental Law: Telling Nature's Time (Cambridge University Press, Cambridge 2017).

16. S Knight, 'The Uncanny Power of Greta Thunberg's Climate-Change Rhetoric', The New Yorker, 24 April $2019<\mathrm{http}$ //www.newyorker.com/news/daily-comment/the-uncanny-powerof-greta-thunbergs-climate-change-rhetoric $>$. 
or delve into particular case studies. Although eclectic in composition, many articles in this special issue focus on protest relating to climate change. The articles are clustered into three areas: analysis of the methods, goals and impact of the XR movement; the roles of public discourse and information in empowering environmental activism in the public sphere; and the contribution of specific protest actors, namely children, youth and Indigenous peoples.

The first two articles focus on the XR movement. Originating in England in May 2018, XR has flourished into a global protest movement that aims to deploy non-violent, mass civil disobedience in order to provoke action by governments to tackle climate breakdown. Extinction Rebellion rejects 'reformist' politics in favour of mass mobilizations in major cities to cause civil disruption that it hopes will compel governments to meet its demands to tell the truth about the climate emergency, dramatically cut carbon emissions and convene citizens' assemblies to debate new policies for social and environmental well-being.

Neil Gunningham, from the Australian National University, critically examines the XR movement's capacity for achieving transformational change, through case studies of XR activities in the UK and Australia and theoretical perspectives about the influence of grassroots, environmental movements. Gunningham finds that such activism is unlikely in its current guise to precipitate rapid action on climate change, but that it may have better prospects when allied to other business and civil society actors that create coalitions or webs of influence. His analysis is informed by direct observation of some XR protests and activities, plus 20 interviews with XR strategists from Australia and the UK, which he selected because these countries have among the most active XR presences in the world. Erica Chenoweth and Maria Stephen's widely cited research, concluding that non-violent civil disobedience has about an even chance of success when at least 3.5 per cent of the population is mobilized to protest, ${ }^{17}$ is doubted by Gunningham. One concern he has is that the examples that Chenoweth and Stephen rely on relate to people directly oppressed by repressive governments that they seek to overthrow, such as the Marcos regime in the Philippines in the 1980s, which Gunningham believes involves different politico-legal contexts than those in which XR activists in Australia and the UK operate.

The second article devoted to XR is a Canadian case study authored by Dana James and Trevor Mack, a scholar at the University of British Columbia and a Tsilhqot'in filmmaker respectively. They examine XR activities in the city of Vancouver, in which they have personally participated, in light of the criticism some have made that XR has given insufficient attention to socio-economic privilege or disadvantage in its supposedly 'apolitical' approach to climate activism. ${ }^{18}$ Sensitive to this critique, James and Mack argue that 'settler colonialism' in Canada, which dispossessed the First Nations of most of their territories, is intertwined with the climate and ecological crises and with settler petro-capitalist strategies, such as government policies authorizing oil pipelines and associated extractive industries on Indigenous peoples' unceded lands. In advocating a 'decolonizing approach' to climate activism that challenges this legacy, James and Mack use

17. E Chenoworth and M Stephen, Why Civil Resistance Works: The Strategic Logic of Nonviolent Conflict (Columbia University Press, New York 2012).

18. See eg, D Gayle, 'Does Extinction Rebellion Have a Race Problem?', The Guardian, 4 October 2019 <http://www.theguardian.com/environment/2019/oct/04/extinction-rebellionrace-climate-crisis-inequality $>$. 
Kyle Powys Whyte's concept of 'decolonizing allyship'19 and suggest three ethics - of relational accountability, care and incommensurability - that climate activist groups such as XR should adopt. Thereby, they believe, XR can overcome its agnosticism to issues of socio-economic status, which the authors see as being particularly important in Canada, and no doubt many other parts of the world. Above all, James and Mack affirm that protests led by Indigenous communities, which in recent years have rallied against fossil fuels infrastructure, should be supported by XR.

The second cluster of articles in the journal special issue examine some cross-cutting underpinnings for activism and protest in the public sphere, focusing on public discourse and information as empowering factors. Francine Rochford, from La Trobe University, investigates her subject matter from Jürgen Habermas' position on the importance of civil disobedience in correcting deficiencies in democratic institutions, especially in regard to 'discursive will formation'. She dissects the preconditions for civil disobedience in contemporary Western societies to fulfil this function, and draws on environmental activism and debate in Australia over recent decades, as well as recent XR protests, to connect her theoretical lens to actual practice. She identifies how the law materially affects opportunities for discursive will formation, such as Australia's constitutionally implied freedom of political communication, which was interpreted by its High Court as overriding elements of anti-protest legislation adopted by the state of Tasmania. Conversely, Rochford identifies the emerging framing of climate breakdown as a 'security issue' akin to a public emergency as a countervailing threat to a vibrant deliberative democracy. Although not covered in her paper, this risk is illustrated well by the Covid-19 pandemic, as readers will have experienced personally, with widespread emergency lockdowns that restrict public gatherings and protest.

Accompanying this exploration of overarching or cross-cutting themes, Anna Berti Suman, from Tilburg University, and her co-authors Sven Schade (European Commission) and Yasuhito Abe (Komazawa University), examine how the production of citizen-generated data (CGD), such as citizen science on biodiversity, can constitute a form of social protest. With a perspective drawing from practices and laws in the European Union and East Asia, the authors argue that CGD can serve not merely as scientific evidence but also as 'rhetorical resources' to support activists' demands, such as environmental justice claims. The authors go further to postulate that CGD could embody a new type of legal right - a right to contribute to environmental information and to participate in debates. They extend their enquiry though a detailed survey of 20 initiatives drawn from a larger sample of 500 that used CGD in environmental policy making. From this study they identify a number of knowledge clusters generated by CGD that can shape environmental discourse by activists such as XR and resulting legal and policy changes, including the 'complementary knowledge cluster' (involving local, granular knowledge at a small scale), the 'missing knowledge cluster' (ie, arguments that challenge institutional decisions that overlook the need to gather data on specific issues) and the 'law enforcement cluster' (ie, how CGD can support actions to promote compliance with the law). A common thread running through these knowledge clusters is the 'legitimation' role that CGD can play in tilting environmental decisions in ways that can support environmental activists and affected local communities.

19. K Powys Whyte, 'White Allies, Let's Be Honest About Decolonization', Yes! Magazine, 3 April $2018<$ http://www.yesmagazine.org/issue/decolonize/2018/04/03/white-allies-lets-behonest-about-decolonization $>$. 
The third set of contributions to this special issue focus on specific actors. One of the most distinguishing features of recent climate rallies and debates is the involvement of children and youth, of whom Greta Thunberg is the most well known internationally. The Swedish teenager shot to global stardom in 2019, with speaking invitations at highlevel events from the United Nations in New York to the World Economic Forum in Davos, and personal meetings with Pope Francis and Barack Obama. With Thunberg and her peers forming the subject of her enquiry, Nicole Rogers, from the University of Southern Cross, identifies and examines four framings of the child in climate change activism and policy reform. She evaluates the extent to which children are transcending their traditional casting as hapless victims of environmental adversity to take on new roles in public debates about climate change, alternative roles that Rogers labels as 'litigant', 'activist' and 'messiah'. Through her examination of popular fiction novels, such as Cormac McCarthy's The Road and Julie Bertagna's Exodus, Rogers finds children portrayed in active and powerful roles aligned to parallel shifts she identifies in climate politics and litigation, despite children being denied the vote and any official function in modern democracies. Climate change lawsuits such as the Juliana case in the United States are enlisting young people as plaintiffs to represent those most imperilled by the policy failures of governments. Though, like the fate of the Juliana case thus far, Rogers concludes that it remains to be seen whether children will successfully instigate serious governmental climate action.

The second article in this cluster looks at Indigenous peoples. Tyler McCreary, from Florida State University, analyses the conflict between Canadian and Witsuwit'en law over proposed hydrocarbon pipelines in western Canada. He situates the conflict in underlying differences between Western and Indigenous worldviews of time and space that mediate people's relationships with the natural world, and extrapolates the legal manifestations and consequences of these space-time differences. Canada's fossil fuel economy, epitomized most strongly by the oil sands industry and its pipelines, argues McCreary, commodifies time and space in a narrow, linear trajectory associated with rapid economic 'progress' that erases both the Indigenous history of the land and its ecological cycles and flows. Canadian law privileges this outlook, as is evident in decision making that favours oil sands and pipeline developments over environmental well-being and First Nations' culture. The law of the impacted Witsuwit'en people in British Columbia, explains McCreary, is embedded in a gift exchange that emphasizes reciprocal relations between people and nature in which the past is valued alongside the present and future, resulting in deeper, intergenerational environmental responsibilities. Recent activism by the Witsuwit'en against proposed pipelines on their unceded land is evaluated by him through these distinct temporalities of the commodity and the gift that underpin the protagonists' legal norms.

Indigenous peoples and youth are also the subject of the final article from Corrie Grosse and Brigid Mark, examining youth activists' aspirations and experiences with regard to the annual UN climate change summits, or 'COPs' (Conference of the Parties). Through their case study of COP25 held in Madrid in December 2019, Grosse and Mark interviewed 25 youth activists to understand how they perceived the meeting and any consideration of their interests in climate action. While youth-led movements for climate justice have garnered considerable media attention in the last few years, the authors found their interviewees to be disappointed about the relevance of the COPs. Grosse and Mark conclude that COP25 was one of the worst UN climate conferences, imposing a "colonized space' that marginalized the voice of youth, especially Indigenous and Global South youth, from the policy negotiations. Distilling insights from their interviewees, Grosse and Mark conclude with some reflections on how to 'decolonize' the COPs, 
a goal that might necessitate refusing to participate in such meetings in order to pursue alternate channels of activism, as other contributors to this special issue consider.

\section{INTERVIEWS WITH XR REPRESENTATIVES AND GREEN PARTY POLITICIANS}

With surging climate activism worldwide, what is the future for conventional green party politics, hitherto regarded by many environmentalists as the main political conduit for progressive environmental policies? The rise of XR and other protest movements mobilizing for civil disruption provokes doubts for some about whether effective change can be achieved through the ballot box in liberal-democratic systems. The world's first green political party established to contest elections was the United Tasmania Group, formed in March 1972 with the aim of preventing other environmental disasters after the destruction that year of Lake Pedder in Tasmania's southwest wilderness for a hydropower scheme. ${ }^{20}$ Marches and protests had failed to save Lake Pedder, so the campaigners turned to mainstream electoral politics. Green parties have since mushroomed around the world, securing a particularly strong presence in the European Parliament recently. ${ }^{21}$ Yet many green parties in other jurisdictions have struggled to resonate with electorates or win seats in legislatures.

Concurrently, the impact of climate activism, especially the XR movement that has made headlines in many countries for its creative and bold campaigning, is coming under greater scrutiny as many reflect on whether civil disobedience will make a difference in preventing climate breakdown. The composition of protest movements, their goals and tactics and future directions, are among the important issues in the spotlight. The Covid-19 pandemic, which has displaced policymakers' attention from climate change, is also complicating assessments of the future influence of grassroots climate activism.

This special issue closes with two sets of interviews with green party politicians and XR representatives, to learn directly, first-hand, from some key participants in both arenas about their views on the foregoing matters and other considerations weighing on the future of progressive politics and activism to address climate breakdown and the broader environmental crisis. We interviewed representatives of XR in the United Kingdom and Australia to explore their views on the goals and tactics of and challenges to the movement. Interviews were conducted in late 2019, and updated in mid-2020, with Claire Burgess (former regional coordinator of XR Southern Tasmania, Australia) and Rupert Read (spokesperson for XR England, and Reader in Philosophy, University of East Anglia). The interviews canvassed their views on the rationale for establishing XR, its goals and tactics, relationships to other climate activist networks, the value in deploying rhetoric about a 'climate emergency', and shifts in future directions for the movement in light of its experiences thus far.

The second set of interviews was conducted in early 2020 with three green party politicians: Paul Manly (MP, House of Commons, Green Party of Canada), Chlöe Swarbrick (MP, New Zealand Parliament, Green Party of Aotearoa New Zealand)

20. S Rainbow, 'Why Did New Zealand and Tasmania Spawn the World's First Green Parties?' (1992) 1(3) Environmental Politics 321.

21. E Graham-Harrison, 'A Quiet Revolution Sweeps Europe as Greens Become a Political Force', The Guardian, 2 June $2019<$ <ttp://www.theguardian.com/politics/2019/jun/02/europeanparliament-election-green-parties-success $>$. 
and Jonathan Bartley (co-leader of the Green Party of England and Wales and councillor on Lambeth Council). Each interviewee responded to the same questions, which probed inter alia how green parties view their role with regard to climate activists and civil disobedience, possible collaborations with such movements, opportunities or barriers to electoral success for green parties, the representation of children and youth in parliamentary democracies, and the relationship between parliamentary systems and XR's proposal for citizens' assemblies.

The responses of the XR representatives and green politicians reveal much common understanding and shared aspirations for climate activism, whether pursued on the streets or through legislatures. Yet, the obstacles faced by both strands of progressive environmental politics in leveraging action suggest that their messaging and tactics will need adjusting if a breakthrough is to be secured soon to avoid the worst of the upheavals of the Anthropocene. This special issue of the Journal of Human Rights and the Environment serves to stimulate further critical debate about these vital matters.

Benjamin J. Richardson

Faculty of Law, University of Tasmania 